\title{
Organisation Support Practices and Its Importance for Repatriates: An Empirical Study
}

\author{
Muniza Aftab ${ }^{1}$, Mohammad Israrul Haque ${ }^{2}$, and Mehraj Udin Ganaie ${ }^{3}$ \\ ${ }^{1}$ Research Scholar, ${ }^{2}$ Professor, ${ }^{3}$ Senior Research Fellow \\ ${ }^{1,2 \& 3}$ Department of Business Administration, Aligarh Muslim University, Aligarh, Uttar Pradesh, India \\ E-Mail: Muniza_aftab@yahoo.co.in
}

\begin{abstract}
Repatriation is a challenge across organizations and requires an organised effort for successful Re-adjustment. While expatriation has gained ample importance, repatriation has received limited attention both from academia and industry. Also, the efforts being placed by the organisations in bringing back the repatriates smoothly have been less than desired. There is unawareness on what organizations are doing for repatriate's easy readjustment on return and what is really important to them. This research paper attempts to understand the current repatriate support practices employed by the organization and also identify those which repatriates find most important.
\end{abstract}

Keywords: Repatriation, Repatriate, Repatriation ReAdjustment, Organization Support Practices

\section{INTRODUCTION}

With an increase in global mobility, the relevance of International Assignments also augmented. The executives are sent overseas to learn the desired skills and get the necessary exposure to operate effectively across borders. There is chain of measures which the management takes care of in order to ensure that these expats are settled in host countries well. Conversely, in the process of transition from expatriation to repatriation, the organisation feel that these employees are just coming back home and this transition should happen on its own. It is observed, that mostly companies fill their top positions mostly by those executives who come with a rounded experience including International work and exposure. Despite of high value of International experience that is seen in the selection of executives, it is rare that organizations laid out articulated programs to make repatriation easy. (Mendenhall et al., 1995).This failure to manage the coming of expatriates is just not creating difficulties at the end of international assignments but also risking the firms' returns from the investment itself. (Breitenmoser \& Bader, 2016).

Many repatriates often end up leaving their organizations and exploring job opportunities outside. It is found that more than 50 per cent of repatriate attrition take place just within the first two years of the return (Brookfield Global Relocation Services, 2015). This is attributed to efforts or rather lack of efforts by the organizations as compared to expatriation. Earlier studies indicate that in most of the companies repatriation is not given any importance or discussed with their returning employees, and those who do provide assistance it is only limited to six months or so. Not even forty percent of companies are involved in career planning on return (Lazarova and Caligiuri, 2001). In another study by Marshall et al (2010) on US employees, twenty-six percent of responding firms offered none of the repatriate support practices and majority of firms were not offering more than two repatriate support practices. The GMAC global relocation services survey (2008) shows that due to absence of efforts on repatriate support practices more repatriate's are leaving in North and South America, Europe, Africa, Asia, and the Middle East. In this study an attempt has been made to understand how the Indian organizations are dealing with their hundreds of returning employees especially in the onsite and offshore working culture as India is said to be the top offshoring destination for IT companies across the world. This means the expected export revenue of the industry is to grow 7 to 9 per cent per year to US\$ 135-137 billion in FY'19. In this study, we understand proactive interventions made by organizations for smooth transition of repatriates. Also, the practices which repatriated consider most important are ranked and analysed.

A. Understanding Repatriation: The term 'Repatriation' got its first attention in the year 1963 by Gullahorn and Gullahorn. He was one of the earliest writers to focus attention on the dynamics of re-entry to one's home culture after an extended stay in a foreign country. Mcdonald and Arthur (2002) defined repatriation as a multidimensional process impacting all the aspects of repatriate with a host of factors that affect adjustment back home. According to their definition, both individuals as well as corporations have a collective impact on repatriation consequence. Also, the aspects like communication, knowledge, expectations, and adjustment are interconnected in the process of repatriation. Repatriation can be defined as the process of returning back home and 'repatriates' are those employees who are coming back after an international project (Lazarova and Caligiuri, 2001).

B. Organizational Support Practices and Repatriation: Organizational support plays a role on the repatriation experience. The organization support practices intensely affect repatriation outcomes and the way repatriate behaves. Also, it is seen that organisation support practices have a significant relationship with reduction in turnover intentions. (Birur and Muthiah, 2013). Repatriates who were supported by their organizations, would want to continue 
working with the same firm upon repatriation (Lazarova and Caligiuri, 2001). On the contrary, the study on Korean repatriates proposed that repatriates think they can manage on own and do not need any help. (Cho et al., 2013). It is seen that repatriates perceive formal repatriation assistance as insufficient. (Osman Gani \& Hyder, 2008). As per Harvey (1989), only 31 percent organizations have repatriation programs, only 22 percent start at expatriation phase. Out of this only 35 percent included spouses and 15percent included children. As per Marshall (2010) logistical assistance like relocation services was offered by 60 percent companies, not even 70 percent provided career and training support for repatriates. Similarly, the skills acquired on the overseas assignment remain unfulfilled. Only 19 percent were ensuring visit back to headquarters or newsletter updates. In addition, Hurn (1999) maintains that the training on repatriation has to be pre-planned much before the return date which would prepare the employees and the companies ready for any possible difficulties.

An effective repatriation program includes repatriation policies to various HR practices, Pre-departure and post arrival orientations, Financial support, communication aspects, assistance to family programs, Job and role support, mentoring, job guarantee on return etc. (Stroh, 1995, Lazarova and Caligiuri, 2001; Lazarova and Cerdin, 2007; Kulkarni et al., 2010; Vidal et al., 2010, Cho et al., 2013; Sreeleakha and Mohan Raj, 2014; Burmeister and Deller, 2016). The selection for overseas assignment should not be dependent on the technical competence but also their adaptibility and desire to relocate (Mendenhall et al., 1987).Repatriates want to have a clear understanding of their role in the form of a career development plan (GomezMejia and Balkin, 1983). They expect counselling, preplanning of return and post arrival orientation (Ahad Osman-Gani, \& Hyder, 2008; Allen and Alvarez, 1998). Pre- departure training makes the expectations meet the reality 'Repatriation training' and helps in better repatriate experiencee and makes their life easier on coming home.(Stroh et al., 1998; Black et al., 1992, Hammer et al., 1998, Harvey, 1989). Training should not be limited to repatriate but also be provided to spouses and family members (Ahad Osman-Gani, \& Hyder, 2008). Nevertheless, an adverse relationship between the post arrival training and the general adjustment of workers has also been found (Vidal et al., 2010). The re-entry briefing is one of the critical aspect of making the employee return smooth. An effective repatriation program costs between $\$ 3500$ and $\$ 10000$ per family (Leslie,2002). Such counselling facilitates a clearer understanding of a more coherent sequence of job assignments (Bailey\& Dragoni, 2013). The buddy system, Mentor Mentee programs can be helpful in re-entry for expatriates are considered to be an effective organisation support (Kendall, 1981; Tung, 1988; Harvey, 1989). Creating repatriate support groups is an important organisational support activity (Halpern, 2005). Another factor of importance with regard to organisational support is Financial Support. On return, the repatriates are back on Indian payroll based on same perks which was before their departure. This usually means decrease in salary leading to dissatisfaction with the readjustment process (Black and Gregersen, 1999; Dowling and Schuler, 1990; Harvey, 1989). As per Black (1992), payment is fundamental to repatriates' levels of satisfaction with 77 per cent were unsatisfied with their compensation system. Although, research has also indicated that payment has a strong opposing association to turnover (Adam et al., 2013).

A two-way communication between the organization and the employee prior to coming home makes smooth transition handy. Targeted and planned communication sets the expectations right (Ahad Osman-Gani, \& Hyder, 2008; Clague and Krupp, 1978; Hammer et al., 1998). The maintenance of the constant contacts between the home office and the expatriate among the top 3 factors that influence successful re-entry (Tung, 1988). In case, there is no touch between friends and co-workers in the home office, many impractical expectations can exist (Stroh et al., 1998). Frequency of visits back to home country and home office can play an important role (Black et al., 1992; Vidal et al., 2010). Communication via technology can be equally satisfying to individuals on overseas assignments as personal visits. (Cox, 2001). Those repatriates who do not have certainty of work or job on return are likely to be more effective (Adler,1981) The repatriate comes back with a mind-set that they are coming after acquiring high end skills and is more knowledgeable about the client. They have clear expectation that their career definetely going up on coming back. But the re-entry process can be distressing when expectations of career progression is not met. Also, it may happen that the new skills acquired at overseas location are not utilised on coming back which leads to frustation (Tung,1988).Role clarity, role descretion \& work autonomy are positively related with work adjustment (Black et al,1991; Baruch et al., 2002) The career management approach on repatriation is more likely to make the employee continue with the company after the assignment ends (Halpern, 2005, Macdonald and Arthur, 2002).

\section{METHODOLOGY}

Hundreds of employees are deployed at client locations with a team at offshore (anywhere in India). The client location and the service company's workplace can be geographically any place - across the globe who returns after the end of the typical assignment of 2-5 years. These returning employees are called as repatriates and focus of this study. Also, in the context of this study, repatriation is defined as the process of return to the home country at completion of an international assignment (Dowling and Schuler, 1990).

A. Research Instrument and Sampling: This study used quantitative research methods and the questionnaires were sent through email or in person through hard copy to Indian IT repatriates .This questionnaire was applicable to those who have returned from overseas assignment of at least 6 months and have returned not more than 3 years back. Snowball method was tactically used and almost 8 months were spent on collecting the data. The follow-ups were 
taken to ensure a satisfactory response rate. The sample size of this study was 202 who were asked to rate the importance of 15 repatriate practices on a five point Likert Scale, from "Not at all as important" to "Very Important" = 5. These practices were identified through literature and mostly adopted from Duoto (2002), Thompson (2007), Lazarova (2000) and then discussed with some HRM professors and practitioners to verify the relevance of these practices with respect to time and geographical area.

B. Profile of Respondents: A total of 202 repatriates working in IT/ITES companies participated in survey (Table I). Male respondents (146/72.3 percent) were more than double that of female respondents (56/27.7 percent), and about same pattern was noticed in case of married (149/73.8 percent) and unmarried managers (53/26.2 percent). More than half of respondents (57.4) fall in the age group of 28 to 35 years, who were in their mid-career life and willing to gain international working experience. An overseas assignment was attractive and appealing to them as it provided the opportunities to develop their managerial skills. About 70 percent of the respondents were engineering and other graduates, 19 percent were Masters in Engineering and Computer Sciences and 11 percent were Master in Business Administration (MBAs). They had the necessary knowledge and skills to handle overseas assignments. About 11 percent of the respondents had overseas assignments less than one year, 59 percent had one to three years, and 30 percent had assignments of longer than three years. It was found that 80 percent of the respondents are actively looking for jobs outside their company after their return, much higher than previous studies 20 percent (Frazee, 1997), which confirms failed repatriation as noted by Black (1992) and is considered as a great loss to the companies (Engen, 1995).

TABle I The Demographic Profile Of The Respondents

\begin{tabular}{|c|c|c|}
\hline & Frequency & Percentage \\
\hline \multicolumn{3}{|c|}{ Gender } \\
\hline Male & 146 & 72.3 \\
\hline Female & 56 & 27.7 \\
\hline Total & 202 & 100.0 \\
\hline \multicolumn{3}{|l|}{ Age } \\
\hline 22-27 Years & 16 & 7.9 \\
\hline 28-35 Years & 116 & 57.4 \\
\hline $36-42$ Years & 57 & 28.2 \\
\hline 43-50 Years & 13 & 6.4 \\
\hline Total & 202 & 100.0 \\
\hline \multicolumn{3}{|c|}{ Education } \\
\hline B.E/B.Tech & 125 & 61.9 \\
\hline Graduation other than Engineering & 16 & 7.9 \\
\hline MCA/M.Tech & 38 & 18.8 \\
\hline MBA/PGDBM & 23 & 11.4 \\
\hline Total & 202 & 100 \\
\hline \multicolumn{3}{|c|}{ Marital Status } \\
\hline Married & 53 & 26.2 \\
\hline Unmarried & 149 & 73.8 \\
\hline Total & 202 & 100.0 \\
\hline \multicolumn{3}{|c|}{$\begin{array}{l}\text { Length of Assignment } \\
\end{array}$} \\
\hline Less than 6 Months & 45 & 22.3 \\
\hline 6-12 months Months & 45 & 22.3 \\
\hline 12-24 Months & 71 & 35.1 \\
\hline 24-36 Months & 41 & 20.3 \\
\hline Total & 202 & 100 \\
\hline \multicolumn{3}{|c|}{ Assignment Seeking } \\
\hline Yes & 162 & 80.2 \\
\hline No & 40 & 19.8 \\
\hline Total & 202 & 100 \\
\hline
\end{tabular}




\section{RESULTS}

The results showed that only 6 out of 15 practices like "proper communication during overseas", "pre-departure briefing", "on return job utilized the acquired knowledge", "job clarity after return", and "frequent communication with parent company" were present as reported by more than 50 percent of the respondents, around 51 to 80 percent of the respondents have reported the absence of 9 out of 15 practices like "reorientation before and on return", "Career Planning Sessions", "Adequate Compensation Package on return" were witnessed by more $70 \%$ of the respondents. This result was in line with earlier findings of 73 percent (Hansen, 1997) and 70 percent (AhadOsman-Gani, \&Hyder, 2008) with no improvement. This high percentage indicates the absence of importance given by companies to develop a repatriation policy for a smooth readjustment (Swaak, 1997).

TABLE II IMPORTANT REPATRIATION PRACTICES

\begin{tabular}{|l|c|c|c|c|c|c|}
\hline Practices & N & Mean & Std. Deviation & Practice Present (n) & \%age & Practice Presence Rank \\
\hline RP10 & 202 & 4.2871 & .88 & 63 & 31.19 & 13 \\
\hline RP12 & 202 & 4.2772 & .88 & 103 & 50.99 & 6 \\
\hline RP1 & 202 & 4.2723 & .68 & 147 & 72.77 & 2 \\
\hline RP14 & 202 & 4.2525 & .63 & 124 & 61.39 & 3 \\
\hline RP15 & 202 & 4.2327 & .79 & 117 & 57.92 & 4 \\
\hline RP11 & 202 & 4.0891 & .86 & 112 & 55.45 & 7 \\
\hline RP7 & 202 & 4.0842 & .96 & 96 & 47.52 & 14 \\
\hline RP6 & 202 & 4.0446 & 1.05 & 59 & 29.21 & 12 \\
\hline RP3 & 202 & 4.0050 & .87 & 71 & 35.15 & 9 \\
\hline RP13 & 202 & 3.9604 & .76 & 162 & 80.20 & 8 \\
\hline RP8 & 202 & 3.9604 & .99 & 81 & 40.10 & 10 \\
\hline RP4 & 202 & 3.8317 & 1.04 & 82 & 40.59 & 11 \\
\hline RP9 & 202 & 3.8119 & 1.07 & 77 & 38.12 & 15 \\
\hline RP2 & 202 & 3.5198 & 1.16 & 73 & 36.14 & 21.29 \\
\hline RP5 & 202 & 3.4901 & 1.29 & 43 & \multicolumn{2}{|c|}{ N Total number of respondents, } \\
\hline
\end{tabular}

$\mathrm{n}=$ number of respondents agreed on presence of practice in their organization

TABLE III SUPPORT PRACTICE REFERENCES FOR RP1 - RP15

\begin{tabular}{|l|l|}
\hline Code & \multicolumn{1}{|c|}{ Repatriate practice } \\
\hline RP1 & Pre-departure briefings before travel (to host country) \\
\hline RP2 & Re-orientation program \&Assistance 3-6 months before return \\
\hline RP3 & Re-orientation program \&Assistance provided immediately before return \\
\hline RP4 & Re-orientation program \&Assistance immediately up on return \\
\hline RP5 & Re-orientation program \&Assistance provided 6 months of return \\
\hline RP6 & Career planning sessions \\
\hline RP7 & Information about possible position in home country on return \\
\hline RP8 & Organization assistance to families with housing issues \\
\hline RP9 & Have a provision of flexible career placement \\
\hline RP10 & Competitive Compensation Package \\
\hline RP11 & Frequent communication with home company during the last 6 months of your time abroad \\
\hline RP12 & Help on Personal finances upon return \\
\hline RP13 & While overseas, receiving information from corporate/home office regularly \\
\hline RP14 & Job on return utilized the knowledge and skills they acquired during international assignment \\
\hline RP15 & Clarity on what the job consisted of after repatriation \\
\hline
\end{tabular}




\section{A. Repatriation Readjustment}

Less than 40 per cent of the respondents' companies provided expatriation reorientation assistance for return, whereas, more than 60 percent maintained communication during expatriation process. Around 70 percent respondent companies did not provide an adequate compensation to their international managers, showing much higher figure than earlier findings of 35 per cent (Harvey, 1989). Almost 62 per cent of the respondents have reported that they did not find flexible career option by their companies on return. Most of the companies may be in a belief that reorientation is not necessary for the returning international managers on their return to home country. The other possible reason could be companies are more concerned of the people on international assignment and find lesser time to focus on their repatriation training and orientation so as to utilize their knowledge. This is in accordance with the findings by Dowling, Schuler, \& Welch (1994), who mentioned that organization's focus is missing on the problem of repatriation when employees are sent back.

As per the respondents all of the identified practices were found quite important as their mean values ranged from 3.49 to 4.29 which tend to importance side of measuring scale. Most important practice "better compensation plans on return" topped the importance list by the respondents, followed by "Help on finances on return", "Pre departure briefing", "Knowledge utilization on return", "Better clarity of job on return" and "better communication with home country and information regarding placement options in home country" (Refer Table II). International managers receive comprehensive training and orientation before moving for international assignment related to job and culture, which makes them easy to adjust in international environment. While, the respondents reported that same was lacking when they returned back to their home country which sometimes becomes partly new to them as well. This indicates that the repatriates would like to have orientation programs that cover both professional and social aspects (Black, Gregersen, \& Mendenhall, 1992).

As per the international managers better compensation plan is the most important factor for companies to retain a repatriate, but has not been found good in case of Indian IT/ITEs companies. Similarly, some other important factors like better personal financial condition on return, information on positions available at home country, career planning, and reorientation before departure and on arrival at home country were found poor as per survey.

\section{DISCUSSION AND CONCLUSIONS}

Many studies have been done on the repatriate support practices from the organization's perspective (Mendenhall et al., 1995, Marshall et al., 2010), this study focuses on both - the organizational \& individual perspective. This gives a clear picture on the provision of the organizations and the requirement of the returnees. It is interesting to note that there may not always be the harmonisation between these offerings and the exact requisite. This will give necessary indication to the organization on the most relevant practices which they should incorporate for their repatriates.

The results show that repatriates have given importance to all the support practices and want their organizations to implement them. This is contrary to the study by Cho et al (2013) where it was shown that repatriates do not feel the need of the support. Also, the results clearly show repatriation support is inadequate in most of the organizations which confirms the concerns as highlighted by Ahad Osman-Gani, \& Hyder (2008). One of the encouraging points, nevertheless, is the connectivity with the home office which is practised in almost 80 percent of organizations contrary to the earlier studies where it was shown fewer than 20 percent (Marshal et al., 2010). It is likely that repatriation is not fully considered before sending employees overseas and there is a lack of planning. There is lack of assistance before 3 months or immediately before return. The efforts after 6 months of return are much minimized and even individuals do not consider this as so important. Immediate actions within 6 months of the return are given most significance by repatriates.

The only harmony between the organization efforts and an individual's necessity can be witnessed in the pre-departure briefings, utilization of skills \& clarity on what the job consisted of. The biggest concern is financial stability for the returning employees and any assistance in this regard is vital to them. The decline in the salary \& compensatory benefits on return is worrisome for employees and unfortunately not adequately managed by the organizations.

The results clearly show that the companies should implement most of the practices identified as all of them are important to the repatriates but assistance in regard with finances is crucial. The organizations should further dig in to understand the aspects of financial benefits which are fundamental for the returnees. This research suggests the pain in readjustment can be eased to an extent if the financial assistance and a competitive compensation on return can be managed.

The high importance on Pre- departure briefings before host country travel also indicates the uncertainty reduction which the repatriates expect. They want to well informed and aware of the challenges they may face on return. The organizations should not wait for the return date finalization on these briefings or expectation settings but they should start at the time of expatriation.

The study demonstrates that career planning is mostly ignored and there is no set plans on how the international experience will be incorporated in the future career plans. However, at the end, the utilization of skills is still higher which indicates that a formalised plan is lacking but post return the repatriates are able to somehow managing to fit into related roles. 
Since, we have identified the most important practices for the repatriate re-adjustment, the future studies can further focus on various aspects within these practices - For eg: Exact facets in compensatory benefits or pre-departure briefings can be identified. Overall, there is a limited effort into repatriation by the management. With hardly any support practice which more than $80 \%$ of the employees have experienced, the focus is required for complete planning as it is done in case of expatriation.

\section{REFERENCES}

[1] Adam H.C., Wuhua C., \& Soongwon Cho. (2013). Determining the Factors Affecting Retention of Employees in Taiwanese Electronic's Firms - General Vs Repatriated Employees, International Journal of Academic Research in Business and Social Sciences, 3(1), 100-118.

[2] Adler, N.J. (1981). Re-entry: Managing cross-cultural transitions. Group and Organizational Studies, 6, 341-356.

[3] Ahad M. Osman-Gani, A., \& Hyder, A.S. (2008). Repatriation readjustment of international managers: An empirical analysis of HRD interventions. Career Development International, 13(5), 456475.

[4] Allen, D., \& Alvarez, S., (1998). Empowering expatriates and organizations to improve repatriation effectiveness. Journal of Human Resource Planning, 21(4), 29-39.

[5] Bailey, C., \& Dragoni, L. (2013). Repatriation after global assignments: Current HR practices and suggestions for ensuring successful repatriation. People and Strategy, 36(1), 48-57.

[6] Baruch, Y., Steele, D., \& Quantrill, G. (2002). Management of expatriation and repatriation for novice global player. Int $J$ of Manpower, 23(7), 659-671.

[7] Birur, S., \& Muthiah, K. (2013). Turnover intentions among repatriated employees in an emerging economy: The indian experience.

[8] Black, J.S. (1992). Coming Home: The-Relationship of Expatriate Expectations with Repatriation Adjustment and Job Performance. Human Relations, 45(2), 177-192.

[9] Black, J.S., Gregersen, H.B. \& Mendenhall, M.E. (1992), Global Assignments: Successfully Expatriating and Repatriating International Managers, Jossey-Bass, San Francisco, CA

[10] Breitenmoser, A., \& Bader, B. (2016). Repatriation outcomes affecting corporate ROI: A critical review and future agenda. Management Review Quarterly, 66(3), 195-234. Doi: http://dx.doi.org/10.1007/s11301-016-0119-6

[11] Brett, J.M., \& Stroh, L.K. (1995), (1986-1998).Willingness to relocate internationally. Human Resource Management 34(3), 405.

[12] Brookfield Global Relocation Services (2015). Global relocation trends 2015 survey report. Brookfield, Woodridge, IL.

[13] Burmeister, A., Deller, J., Osland, J., Szkudlarek, B., Oddou, G., \& Blakeney, R. (2015). The micro-processes during repatriate knowledge transfer: The repatriates' perspective. Journal of Knowledge Management, 19(4), 735-755.

[14] Cox, J.B. (2001).The impact of information and communication technology on cultural re-entry adjustment, Dissertations Abstracts International, 110

[15] Cho, T., Hutchings, K. \& Marchant, T. (2013). Key factors influencing Korean expatriates' and spouses' perceptions of expatriation and repatriation

[16] Christofi, V., \& Thompson, C.L. (2007). You cannot go home again: A phenomenological investigation of returning to the sojourn country after studying abroad. Journal of Counseling and Development: $J C D, 85(1), \quad 53-63 . \quad$ doi: http://dx.doi.org/10.1002/j.1556-6678. 2007.tb00444.x.

[17] Clague, L., \& Krupp, N. (1978). International personnel: The repatriation problem. Personnel Administrator, 23, 29-33.
[18] Dowling, P.J \& Schuler, R.S., (1990). International Dimensions of Human Resource Management, Boston MA: PWS-Kent.

[19] Dowling, P.J., Schuler, R.S. and Welch, D.E. (1994), International Dimension of Human Resource Management, Wadsworth, Belmont, $C A$.

[20] Duoto, M.A. (2002). Factors influencing job satisfaction of repatriated managers (Doctorate of Education). Retrieved from ProQuest Dissertations and Theses. (Accession Order No. AAT 3077841).

[21] Engen, J.R. (1995). Coming home. Training, 32(3), 37-43.

[22] Frazee, V. (1997). Welcome your repatriates home. Workforce, April, pp. 24-8.

[23] Gomez- Mejía, L., \& Balkin, D. (1987). The Determinants of Managerial Satisfaction with the expatriation and Repatriation Process. Journal of Mgmt Development, 6(1), 7-17.

[24] Gullahorn, J., \& Gullahorn, J. (1963). An Extension of the U-Curve Hypothesis. Journal of Social Issues, 19(3), 33-47.

[25] GMAC Global Relocation Services (2008), Survey Report, GMAC Global Relocation Services, Woodridge, IL.

[26] Hammer, M.R., Hart, W. \& Rogan, R. (1998), Can you go home again? An analysis of the repatriation of corporate managers and spouses. Management International Review, 38(1), 67-86.

[27] Hansen, F. (1997). Repatriation programs work. Compensation \& Benefits Review, 29(5), 14-15.

[28] Harvey, M.G. (1989). Repatriation of corporate executives: an empirical study. Journal of International Business Studies, Spring, $131-44$.

[29] Halpern, J. (2005). The dilemma of repatriation: Managing expatriate expectations (Doctorate of philosophy). New York University.

[30] Hurn, B. (1999). Repatriation - the toughest assignment of all. Industrial and Commercial Training, 31(6), 224-228.

[31] Kendall, D. (1981). Repatriation: An ending and a beginning. Business Horizons, 24(6), 21-25.

[32] Kulkarni, M., Lengnick-Hall, M., \& Valk, R. (2010). Employee perceptions of repatriation in an emerging economy: The Indian experience. Human Resource Management, 49(3), 531-548.

[33] Lazarova, M., \& Caligiuri, P. (2001). Retaining repatriates: The role of organizational support practices. Journal of World Business, 36(4), 389-401.

[34] Lazarova, M., \& Cerdin, J. (2007). Revisiting repatriation concerns: organizational support versus career and contextual influences. Journal of International Business Studies, 38(3), 404-429.

[35] Leslie, G.K. (2002). The right way to bring expats home. Workforce, 81(7), 40-44.

[36] MacDonald, S., \& Arthur, N. (2002). Employees' perception of Repatriation. Career DevInt, 10(2), 145-159.

[37] Marshall, P., White, M.M., \& Tansky, J. (2010). The homecoming: A review of support practices for repatriates. Career Development International, 15(4), 359-377.

[38] Mendenhall, M.E., Punnett, B.J. \& Ricks, D.A. (1995), Global Management, Blackwell, Cambridge.

[39] Sánchez Vidal, M., Sanz Valle, R., \& Barba Aragón, M. (2010). Analysis of the repatriation adjustment process in the Spanish context. Int J Of Manpower, 31(1), 21-41.

[40] Swaak, R. (1997). Repatriation: a weak link in global HR. HR Focus, 74(4), 29-30

[41] Sreelekha, P., \& Mohan Raj, P (2014). An Examination of Factors Influencing Repatriates' Loyalty, Int. J. Manag. Bus. Res., 4(4), 255264.

[42] Stroh, L., Gregersen, H., \& Black, J. (1998). Closing the gap: Expectations versus reality among repatriates. Journal of World Business, 33(2), 111-124.

[43] Tung, R. (1988). Career Issues in International Assignments. Academy Of Management Executive, 2(3), 241-244.

[44] Valk, R., Van, d. V., Marloes, V. E., \& Szkudlarek, B. (2015). Warm welcome or rude awakening? Journal of Indian Business Research, 7(3), 243-270. doi:http://dx.doi.org/10.1108/JIBR-092014-0064. 